\title{
Schweitzerowska kategoria odpowiedzialności jako filozoficzna podstawa zrównoważonego rozwoju
}

\begin{abstract}
Albert Schweizter - geniusz XX wieku
Albert Schweitzer urodził się 14 stycznia 1875 w w Kayserbergu w Górnej Alzacji, zmarł 4 września 1965 w Lambaréné w Gabonie. Studiował na Uniwersytetach w Strasburgu i Sorbonie, po uzyskaniu doktoratu z filozofii oraz habilitacji z teologii rozpoczął studia medyczne, po ich ukończeniu niósł pomoc Afrykańczykom, w założonym przez siebie szpitalu w 1913 roku w Lambaréné (Gabonie).

Jak mawiał o nim Albert Einstein geniusz XX wieku. Schweitzer był teologiem luterańskim, misjonarzem, duszpasterzem, lekarzem - humanistą i społecznikiem, wielkim orędownikiem pokoju, równości ludzi, narodów i religii oraz laureatem Pokojowej Nagrody Nobla (1953 r). Albert Schweitzer to także genialny organista i muzykolog, znawca Jana Sebastiana Bacha. Niezrównany myśliciel, filozof i etyk, prekursor etyki środowiskowej oraz pionier współczesnej ekologii i myślenie opartego na współczesnych zasadach zrównoważonego rozwoju.

\section{Zrównoważony Rozwój}

Zrównoważony rozwój jest filozofią rozwoju społeczno - ekonomicznego zharmonizowanego z dbałością o stan środowiska naturalnego. Umożliwia pogodzenie dążenia człowieka do osiągnięcia wysokiego poziomu ekonomicznego rozwoju połączonego z troską o środowisko społeczne i przyrodnicze. Interpretacja pojęcia zrównoważony rozwój (odnosząca się do harmonijnego rozwoju polityczno - społeczno - gospodarczego w uwzględnieniem troski o środowisko przyrodnicze) pojawiła się po raz pierwszy w Raporcie Światowej Komisji Środowiska i Rozwoju „Nasza wspólna przyszłość” w 1987, a rangę międzynarodową pojęcie zrównoważonego rozwoju uzyskało w 1992 podczas Konferencji Narodów Zjednoczonych: Środowisko i rozwój (Szczyt Ziemi w Rio de Janeiro).
\end{abstract}


Ustawa Prawo ochrony środowiska z dnia 27 kwietnia 2001 r. Dział II, art. 3, pkt 50, prezentuje definicję pojęcia zrównoważonego rozwoju:

- zrównoważony rozwój - rozumie się przez to taki rozwój społeczno-gospodarczy, w którym następuje proces integrowania działań politycznych, gospodarczych i społecznych, z zachowaniem równowagi przyrodniczej oraz trwałości podstawowych procesów przyrodniczych, $\mathrm{w}$ celu zagwarantowania możliwości zaspokajania podstawowych potrzeb poszczególnych społeczności lub obywateli zarówno współczesnego pokolenia, jak i przyszłych pokoleń ${ }^{1}$.

Pojęcie zrównoważonego rozwoju opiera się na kategorii odpowiedzialności człowieka za jego czyny w stosunku do samego siebie, obecnego i przyszłych pokoleń, krajów sąsiednich, a zwłaszcza środowiska przyrodniczego. Bez zdania sobie sprawy z tej odpowiedzialności cała filozofia i idea zrównoważonego rozwoju najprawdopodobniej by nie powstała. Dlatego można pokusić się o uzupełnienie definicji zrównoważonego rozwoju, poprzez zaakcentowanie właśnie opisanej wyżej odpowiedzialności. Tak uzupełniona definicja prezentowałaby się w następujący sposób:

- zrównoważony rozwój - rozumie się przez to taki rozwój społeczno-gospodarczy, w którym następuje proces integrowania odpowiedzialnie podejmowanych działań politycznych, gospodarczych i społecznych, z zachowaniem równowagi przyrodniczej (ponoszeniem odpowiedzialności za działania mające wpływ na przyrodę) oraz odpowiedzialnością za zachowanie trwałości podstawowych procesów przyrodniczych, w celu zagwarantowania możliwości zaspokajania podstawowych potrzeb poszczególnych społeczności lub obywateli zarówno współczesnego pokolenia, jak i przyszłych pokoleń. Tak ujęta definicja zrównoważonego rozwoju byłaby najprawdopodobniej postulowana przez Alberta Schweitzer, który był jednym z prekursorów myślenia ekologicznego, zgodnie ze współczesnymi zasadami zrównoważonego rozwoju, opartego na odpowiedzialności człowieka za przyrodę. Albert Schweitzer jest twórcą programu moralnego określonego mianem Etyki czci dla życia, w której wielką rolę odgrywa odpowiedzialność człowieka wobec wszelkich przejawów życia, odpowiedzialność, która decyduje o jego człowieczeństwie.

\section{Etyka czci dla życia}

W 1915 roku A. Schweitzer stworzył program moralny, który nazwał Etyką czci dla życia. Jego podstawowym przesłaniem (ideą etyczną) jest stwierdzenie: „Jestem życiem, które chce żyć wśród innego życia, które też chce żyć. Muszę więc szanować życie."

Ustawa Prawo ochrony środowiska z dnia 27 kwietnia 2001.

A. Schweitzer, Z mojego życia..., przeł. Salamon I., Warszawa : Pax, 1981, s. 116. 
Etyka czci dla życia jest etyką uniwersalną, ponadgatunkową i zgodną z naturą człowieka, opartą na solidarności ze wszystkimi przejawami życia. „Realizacja tego programu wymaga od ludzi: dobroci, trudu i odpowiedzialności”’3.

Konsekwencją tego Schweitzerowskiego programu etycznego jest obowiązek ratowania wszelkiego życia oraz łagodzenia cierpienia i bólu. Schweitzer głosił, że cześć dla życia wymaga szacunku, nie tylko wobec ludzi, ale także wobec zwierząt, oraz roślin ${ }^{4}$. „Jest etyczny tylko wówczas, jeśli mu zarówno życie rośliny i zwierzęcia, jak też życie człowieka jest święte, i jeśli jest w stanie ofiarować się życiu, które jest w potrzebie." ${ }^{5}$

Albert Schweitzer w swojej Etyce czci dla życia nadaje właściwą hierarchię światu, środowisku, człowiekowi i innym elementom środowiska przyrodniczego. „Stąd wypływają ujęcia kosmocentryczne, a nie geocentryczne, bio - lub pancentryczne a nie homo - lub antropocentryczne"6. Schweitzer proponuje uznać człowieka nie za pana przyrody, lecz za jej integralną częśćc ${ }^{7}$ „Etyka szacunku dla życia mieści więc w sobie wszystko, co może być nazwane miłością, poświęceniem, współczuciem, współradością i współdążeniem." Uważał on, że współczesna mu etyka zajmująca się wyłącznie zagadnieniem moralności ludzi w stosunku do ich własnego gatunku, jest niewystarczająca i nie pełna. Postulował więc rozszerzenie zainteresowań etyki o stosunek człowieka do wszelkich istot żywych przyrodniczego i całego środowiska przyrodniczego. Schweitzer wzbogaca zasady Etyki czci dla życia nakazami dotyczącymi np. aktywnej postawy i działań człowieka wobec środowiska przyrodniczego, oddawania sprawiedliwości za wyrządzone szkody w środowisku. „Etycznym jest człowiek tylko wtedy, gdy dlań życie jako takie, zarówno rośliny jak i zwierzęta, jest święte, a oddaje się z pomoca temu życiu w potrzebie". 9

Stosunek człowieka do środowiska przyrodniczego zależy głównie nie tyle od zasad etycznych i moralnych, lecz od użyteczności i bezużyteczności elementów

3 B. KRYK, Etyka środowiskowa a potrzeby ekologiczne konsumentów, „Zeszyty Naukowe Uniwersytetu Szczecińskiego", Nr 408, 2005, s. 141 - 159.

4 W stanowiskach etyk nieantropocentrycznych: biocentryzmie i ekocentryzmie (przedstawicielami oprócz A. Schweiztera są np. T. Regan, A. Leopold, J. Lovelock czy A. Ness) lista przedmiotów moralności obejmuje oprócz człowieka także elementy środowiska przyrodniczego. A. Pawıowski, Bariery we wdrażaniu zrównoważonego rozwoju - spojrzenie ekofilozofa, „Problemy ekorozwoju” 2007, Nr 2, s. 62.

A. Schweitzer, $Z$ mojego życia..., przeł. Irena Salamon . Warszawa : Pax, 1981.

6 H. Gaertner, Albert Schweitzer i jego zasada czci dla życia a współczesna ekologia, <http:// zb.eco.pl/zb/20/schweitz.htm>, 16.10.2010; H. GAERTNER, Albert Schweitzer i jego zasada czci dla życia a współczesna ekologia, „Zielone Brygady”, $1991 \mathrm{Nr} 2$.

7 A. Bieniasz, Kategoria odpowiedzialności w myśli Alberta Schweitzera, „Problemy ekorozwoju” 2006, Nr 2, s. 116.

8 A. Schweitzer, $Z$ mojego życia... , przeł. Salamon I., Warszawa : Pax, 1981.

9 Ibidem. 
tego środowiska z ekonomicznego punktu widzenia. Według Alberta Schweitzera człowiek prowadzi niszczycielską gospodarkę, polegającą na niepohamowanym i destruktywnym czerpaniu z dóbr całej przyrody ożywionej i nieożywionej: fauny, flory, wód, ziemi, kopalin i powietrza. Ten antropogeniczny rabunek prowadzi do dalszych, coraz to groźniejszych zmian zachodzących w środowisku naturalnym, stanowiącym środowisko życia człowieka. Człowiek jest więc niszczycielem przyrody, a jak mawiał Schweitzer „natura nie jest i nie może być wyłącznie obiektem i rzeczą, przedmiotem ludzkiej eksploatacji i interesów, należy ponieść odpowiedzialność za swoje czyny w stosunku do środowiska” ${ }^{10}$.

Postępowanie zgodnie z zasadami etyki Schweiztera pociąga za sobą konieczność zmiany stosunku człowieka do samego siebie i otaczającego go świata. „Im bardziej zdajemy sobie sprawę ze swojego faktycznego stanu posiadania, tym większa w prosty sposób jest nasza wdzięczność za to wobec życia, tym silniejsza jest chęć spłaty swoistego długu, bądź przez uprzejmość i życzliwość wobec innych, bądź poprzez troskę o piękny ogród"11.

Albert Schweitzer opisał w swej filozofii czci dla życia opisał sposób, w jaki człowiek powinien zachowywać się wobec zwierzą ${ }^{12}$ i przyrody nieożywionej, oraz jak stać się odpowiedzialnym za swoje czyny, które mają wpływ na otaczający człowieka świat przyrody ożywionej i nieożywionej. Etyka Schweitzera postuluje szacunek dla każdego życia. Nakazuje chronić, szanować i być odpowiedzialnym za wszystko, co żyje na świecie, a na co nasze działania mają wpływ.

\section{Schweitzerowska Etyka czci dla życia inspiracją idei rozwoju zrównoważonego}

W ramach Etyki czci dla życia pojawia się kategoria odpowiedzialności, jako wyraz tej właśnie czci. Odpowiedzialność ta oznacza relacje człowieka względem fenomenu życia i środowiska przyrodniczego jako miejsca bytowania istot żywych.

Schweitzerowska „Etyka czci dla życia” jest jedną z etyk skoncentrowanych na fenomenie życia, obejmującą moralnością nie tylko człowieka ale i wszystkie przejawy życia na świecie.

Schweitzer formułując moralny imperatyw narzuca człowiekowi ponoszenie odpowiedzialności za wszelkie formy życia oraz podejmowane działania wobec środowiska przyrodniczego. Ta właśnie odpowiedzialność stanowi filozoficzną podstawę współczesnej idei zrównoważonego rozwoju.

10 A. Schweitzer, $Z$ mojego życia..., przeł. Salamon I. , Warszawa : Pax, 1981.

11 H . Geartner, Znaczenie etyki „czci dla życia” dzisiaj, Zielone Brygady nr 2 (32) 1992.

12 J. LeJMAN, Etyka zwierząt w świetle idei zrównoważonego rozwoju (szkic filozoficzno-kulturowy), „Problemy ekorozwoju” 2006, Nr 2, s. 102. 
Według Schweitzera trudno jest określić granice odpowiedzialności. Musi objąć ona nie tylko samego człowieka, „czy wszystkich ludzi „z którymi się on styka", sięga także poza pole relacji międzyludzkich wkraczając w świat przyrody"13. Człowiek ponosi odpowiedzialność za środowisko przyrodnicze, w którym żyje, a którego stanowi integralną i nieodłączną część.

Schweitzer zdawał sobie sprawę, że nie ma idealnej etyki. Wynika to z prawa natury: walki o życie i byt, sprawiającej, że jedno życie toczy się kosztem innych. „Jeden byt usiłuje zachować siebie kosztem drugiego, jeden niszczy drugi" ${ }^{14}$. Dlatego Schweitzer karze traktować odpowiedzialność nie jako samo bycie w świecie, lecz jako współbycie ze wszystkimi innymi istotami żywymi występującymi w świecie przyrodniczym ${ }^{15}$. Człowiek jako istota etyczna według A. Schweitzera powinien usiłować, gdzie tylko może, unikać konieczności życia kosztem innych istot żywych i jako ktoś, kto jest świadomy i miłosierny, powinien poczuwać się do odpowiedzialności za to jak daleko sięga zakres jego negatywnego wpływu na środowisko jego życia - środowisko przyrodnicze. ${ }^{16}$

Schweitzer wyznaje: „I ja podlegam samorozłamowi woli życia. Na tysiąc sposobów mój byt jest w konflikcie z innymi. Aby utrzymać moje istnienie, muszę bronić się przed istotami, które mi szkodzą. Moje pożywienie uzyskuję przez niszczenie roślin i zwierząt"17. Jednak nigdy nie można zrzucić z siebie odpowiedzialności za swoje czyny. „Kiedy ratuję jakiegoś owada, po prostu wynagradzam choćby częściowo nieustanną krzywdę, jaką ludzie wyrządzają przyrodzie"18.

Schweitzer opisał w etyce czci dla życia wizję, zachowania się człowieka wobec świata przyrody (ożywionej i nieożywionej, podkreślając konieczność szacunku wszelkich przejawów życia). Nakazuje człowiekowi także stać się odpowiedzialnym za swoje czyny, które mają wpływ na otaczający człowieka świat przyrody ożywionej i nieożywionej. Jego etyka jest etyką odpowiedzialności, która obejmuje wszelkie przejawy życia (roślin, zwierząt i ludzi).

Chcąc żyć etycznie nie można pozbyć się odpowiedzialności, narzuconej przez Schweitzera. „Człowiek, zastanawiający się nad swoim życiem i nad związkiem łączącym go ze światem, musi dojść - zdaniem Schweitzera - do poczucia czci wobec własnego życia i wszelkiego życia” ${ }^{19}$. To właśnie poczucie czci dla wszelkie-

13 A. Bieniasz, Kategoria odpowiedzialności w myśli Alberta Schweitzera, „Problemy ekorozwoju” 2006, Nr 2, s. 115.

14 A. Schweitzer, Z mojego życia... , przeł. Salamon I., Warszawa: Pax, 1981.

15 A. Bieniasz, Kategoria odpowiedzialności w myśli Alberta Schweitzera, „Problemy ekorozwoju” 2006, Nr 2, s. 116.

16 A. Schweitzer, $Z$ mojego życia... , przeł. Salamon I. , Warszawa: Pax, 1981.

17 Ibidem.

18 Ibidem.

19 K. Polus-Rogalika, Geneza i główne założenia etyki środowiskowej w świetle zasady zrównoważonego rozwoju, <http://filozofia-polus.republika.pl/etyka.html>, 16.10.2010. 
go życia związane jest nierozerwalnie odpowiedzialnością za wszelkie istoty żywe. Egzystencja człowieka staje się przez tą odpowiedzialność dużo trudniejsza, „niż gdyby człowiek żył tylko dla siebie"20. Jednak życie człowieka staje się dzięki niej bogatsze, szczęśliwsze i piękniejsze, ponoszenie tej odpowiedzialności jest podstawą ludzkiej godności, to ona stanowi o naszym człowieczeństwie.

Człowiek, aby uchronić od zagłady swój gatunek, musi doświadczyć według Alberta Schweitzera poczucia jedności ze wszystkimi istotami żywymi. Musi zdać sobie sprawę z konsekwencji swojego postępowania, z wywieranej presji antropogenicznej, polegającej na niszczeniu życia i degradacji środowiska przyrodniczego.

Człowiek żyjący zgodnie z etyką czci dla życia wytwarza w sobie światopogląd ekologiczny, który doprowadzi go do czynów podnoszących szacunek dla życia, przeciwstawiających się degradacji środowiska, pozwoli przeciwstawić się zagrożeniom zdrowia i życia ludzkiego (wynikającym z niewłaściwie prowadzonej działalności antropogenicznej) oraz umożliwi żyć zgodnie z ideą i zasadami zrównoważonego rozwoju. A przede wszystkim jak zaznacza Schweitzer pozwoli człowiekowi rozwinąć jego człowieczeństwo i stać się w pełni istotą ludzką.

Tak pojmowana odpowiedzialność człowieka wobec całej przyrody, wynikająca z ponadczasowej Schweitzerowskiej Etyki czci dla życia pozwala przeciwdziałać współczesnym problemom ekologicznym oraz wskazuje metody, za pomocą których można się im przeciwstawiać.

Odpowiedzialność w ujęciu Schweitzera jest wielowątkowa. Można wyznaczyć cztery podstawowe zagadnienia:

- odpowiedniego sytuowania się człowieka w przyrodzie, której jest integralną częścią,

- umiejętnego wartościowania,

- odpowiedzialnego myślenia o świecie, w którym żyjemy,

- odpowiedzialnego działania, które powinno być oparte na etyce czci dla wszelkich przejawów życia ${ }^{21}$.

Według Alberta Schweitzera musimy nauczyć się żyć w harmonii z przyrodą. Założenia Schweitzerowskiego nurtu filozoficznego kładą zgodnie ze współczesną ideą zrównoważonego rozwoju, także duży nacisk na dbanie o stan środowiska przyrodniczego oraz zapewnianie harmonijnego z przyrodą zaspakajaniu potrzeb obecnych i przyszłych pokoleń.

Nawiązując do współczesnej idei zrównoważonego rozwoju odpowiedzialność Schweitzerowska wiąże się z odpowiedzialnością za:

\footnotetext{
20 Ibidem.

21 A. Bieniasz, Kategoria odpowiedzialności w myśli Alberta Schweitzera, „Problemy ekorozwoju” 2006, Nr 2, s. 117.
} 
— zdanie sobie sprawy, z faktu, że nasze działania mają wpływ na środowisko przyrodnicze,

- dbanie o bioróżnorodność przyrodniczą,

- prowadzenie racjonalnej eksploatację zasobów naturalnych,

- wybór odpowiednich sposobów prowadzenia gospodarki, technik wytwarzania i wzorców konsumpcji, które będą prowadziły do minimalizowania negatywnego oddziaływania na środowisko naturalne,

- konieczność dbania o przyszłe pokolenia.

Dlatego też można powiedzieć, że Albert Schweitzer jest nie tylko prekursorem współczesnej etyki środowiskowej ale jest także jednym z prekursorów myślenia opartego na idei zrównoważonego rozwoju.

\section{Podsumowanie}

Kategoria odpowiedzialności Etyki czci dla życia została przywołana, aby wskazać, że idea zrównoważonego rozwoju była obecna w filozofii Europejskiej od dawna. Czekała on na swój czas, który uwyraźni jej znaczenie dla całego świata. Taki czas nadszedł, gdy uświadomiono sobie kryzys współczesnej cywilizacji, wyrażający się także kryzysem ekologicznym. Jedną z tych „ukrytych” idei obok dorobku Św Franciszka z Asyżu czy Św. Hildegardy z Bingen, jest właśnie Schweitzerowska Etyka czci dla życia. Filozofia zrównoważonego rozwoju jest podsumowaniem dorobku kultury Europejskiej zatroskanej o życie i środowisko przyrodnicze.

\section{Bibliografia}

Bieniasz A., 2006, Kategoria odpowiedzialności w myśli Alberta Schweitzera, „Problemy ekorozwoju”, Nr 2, s. 115-118.

GAERTNer H., A. Schweitzer i jego zasada czci dla życia a współczesna ekologia, <http://zb.eco.pl/ $\mathrm{zb} / 20 /$ schweitz.htm>, 16.10.2010.

Geartner H., Znaczenie tyki „czci dla życia” dzisiaj, Zielone Brygady nr 2 (32) 1992.

Howaniec M., 2008, Cześć dla życia. Jej znaczenie w ochronie środowiska uwarunkowania kulturowe, „Dzikie Życie”, Nr 5.

Квук B., 2005, Etyka środowiskowa a potrzeby ekologiczne konsumentów, „Zeszyty Naukowe Uniwersytetu Szczecińskiego", Nr 408, s. 141 - 159.

LEJMAN J., 2006, Etyka zwierząt w świetle idei zrównoważonego rozwoju (szkic filozoficzno - kulturowy), „Problemy ekorozwoju”, Nr 2, s. 99 - 105.

PAPUZiŃski A., 2006, Filozoficzne aspekty zrównoważonego rozwoju - wprowadzenie, „Problemy ekorozwoju", Nr 2, s. 25 - 32.

PAwєowsкi A., 2007, Bariery we wdrażaniu zrównoważonego rozwoju - spojrzenie ekofilozofa, „Problemy ekorozwoju”, Nr 2, s. 59 - 65.

Polus-Rogalska K., Geneza i główne założenia etyki środowiskowej w świetle zasady zrównoważonego rozwoju, <http://filozofia-polus.republika.pl/etyka.html>, 16.10.2010.

Schweitzer A., Z mojego życia..., przeł. Salamon I. Warszawa : Pax, 1981. 
Strategia zrównoważonego rozwoju 2025, <http://www.nape.pl/Portals/NAPE/docs/akty_prawne/ strategie/strategie/Strategia_zrownowazonego_rozwoju_2025.pdf>, 16.10.2010.

Ustawa Prawo ochrony środowiska z dnia 21.04.2001 r.

\section{SCHWEITZER'S SOURCE OF THE CONTEMPORARY IDEA OF THE SUSTAINABLE DEVELOPMENT}

\section{SUMMARY}

The sustainable development is philosophy of the economic development harmonized with the care of the natural environment. It enables to combine the aspiration of the man to achieving the high of the economic development combined with concern against the social and natural environment. One of precursors of the ecological thinking, according to contemporary principles of the sustainable development was Albert Schweitzer. The author of the moral program specific by the name Ethics for the life, in which huge role playing the responsibility, which is deciding on his humanity. This responsibility constitutes the philosophical base of the contemporary idea of the sustainable development.

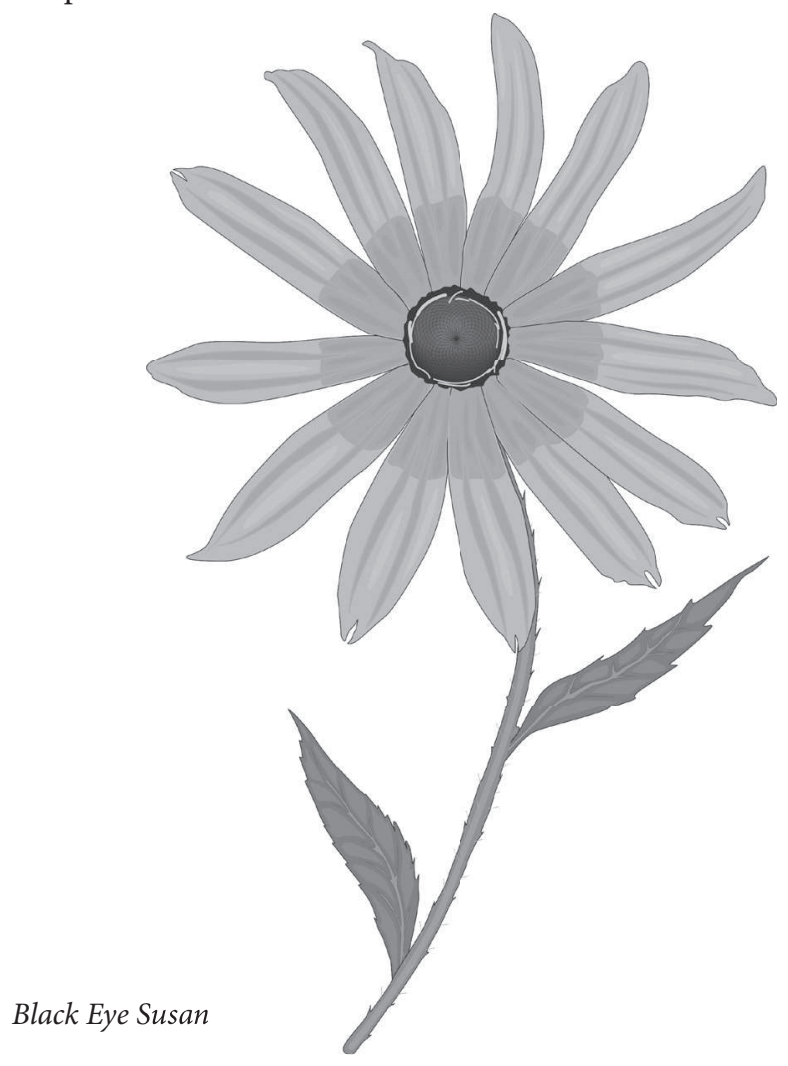

